austro-węgierskiego regimentu, ale także jego składu narodowościowego i wartości bojowej.

Z kolei mgr Wojciech Grajewski przedstawił referat „Między Ojczyzną-Austrią a Ojczyzną-Polską. Cieszyńscy Polacy w latach 1914-1918”. Scharakteryzował w nim postawy miejscowej ludności wobec zmieniającej się sytuacji sprawy polskiej w toku wielkiej wojny.

Po przerwie zostały wygłoszone jeszcze dwa referaty. Jako pierwszy głos zabrał dr Jerzy Z. Pająk, który wystąpił z tekstem „Akcja werbunkowa i propagandowa na rzecz Legionów Polskich w Zagłębiu Dąbrowskim (1914-1916)". Ostatnim referentem był Kamil Ruszała, który wygłosił referat „Badania nad grobami żołnierskimi z I wojny światowej na Śląsku Cieszyńskim oraz Czeskim”.

Jarosław Centek

DOI: http://dx.doi.org/10.12775/EO.2012.016

\title{
General Stanisław Maczek i jego żołnierze w Collegium Humanisticum UMK w Toruniu
}

$\mathrm{W}$ dniu 20 listopada 2012 r. na Wydziale Historii i Archiwistyki Uniwersytetu Mikołaja Kopernika w Toruniu została uroczyście otwarta wystawa poświęcona historii 1. Dywizji Pancernej Polskich Sił Zbrojnych na Zachodzie. Wystawa została przygotowana przez członków Stowarzyszenia Miłośników Artylerii i Militariów oraz Muzeum Wojsk Lądowych w Bydgoszczy. Pomocy w przygotowaniu ekspozycji udzielili studenci unikatowego - jedynego w Polsce - kierunku ,wojskoznawstwo" prowadzonego na Wydziale Nauk Historycznych Uniwersytetu Mikołaja Kopernika w Toruniu.

$\mathrm{Na}$ wystawie, składającej z 46 plansz, została przedstawiona sylwetka gen. Stanisława Maczka oraz szlak bojowy dowodzonej przez niego 10. Brygady Kawalerii Zmotoryzowanej we wrześniu 1939 r. Jedyna w przedwojennym Wojsku Polskim pełnowartościowa jednostka zmotoryzowana brała udział w walkach odwrotowych i działaniach opóźniających w składzie najpierw Armii „Kraków”, potem Armii „Karpaty” („Małopolska”). W ciężkich walkach brygada zadała niemieckiemu XXII Korpusowi Pancernemu ciężkie straty w bitwach pod Jordanowem, Wiśniczem, Łańcutem i Rzeszowem. Od 15 września 1939 r. walczyła na przedpolach Lwowa, jednak 
już 18 września, po wkroczeniu Armii Czerwonej do Polski, na rozkaz Naczelnego Wodza żołnierze 10. Brygady Kawalerii Zmotoryzowanej zostali zmuszeni wraz z całą jednostką do przerwania walki z Niemcami i - uprzedzając nadciagające oddziały szybkie (pancerne i kawaleryjskie) Armii Czerwonej - do przekroczenia granicy polsko-węgierskiej.

Na wystawie można również zobaczyć dalsze losy gen. Maczka, który już we Francji w 1940 r. stanął na czele odtworzonej 10. Brygady Kawalerii Pancernej (10éme Brigade de cavalerie blindée). Z nią wyruszył na front w Szampanii. Tam, wraz z częścią Brygady, wziął udział m.in. w walkach odwrotowych francuskiej 20. Dywizji Piechoty pod Champaubert-Mongivroux, a potem wraz z elementami 59. Dywizji Piechoty walczył w rejonie bagien Saint Gond. Na skutek nieprzemyślanego rozkazu, z francuskiego dowództwa nakazującego zajęcie Montbard i mostów na Kanale Burgundzkim, resztki brygady Maczka zostały odcięte. Generał wydał rozkaz o zniszczeniu sprzętu i przebił się wraz z pół tysiącem swych żołnierzy do Marsylii. Stamtąd przez Tunis, Maroko, Portugalię i Gibraltar dotarł do Szkocji.

Ciekawym fragmentem wystawy są plansze prezentujące Polskie Siły Zbrojne w latach 1943-1945. To właśnie wtedy sformowano i wprowadzono do boju 1. Dywizję Pancerną Polskich Sił Zbrojnych. Na wystawie można zobaczyć fotografie obrazujące jej walki od 1 sierpnia 1944 r., tj. od chwili lądowania dywizji w Normandii, w pobliżu Caen. Została ona przydzielona do 2. Korpusu Kanadyjskiego. Generał Maczek dowodził swą dywizją w zwycięskiej bitwie pod Falaise, gdzie zdecydowana obrona Mont Ormel (Wzgórze 262 znane też jako „Maczuga”) przez polskich żołnierzy uniemożliwiła większej grupie rozbitków niemieckiej 7. Armii wydostanie się z kotła. Dnia 8 sierpnia 1944 r. ruszyło natarcie wzdłuż szosy Caen-Falaise. W ciągłych walkach z siłami Wehrmachtu i Waffen-SS gen. Maczek prowadził dywizję w kierunku Belgii i Holandii. Wyzwolił m.in. Ypres, Gandawę i Passchendaele. Dzięki znakomitemu manewrowi oskrzydlającemu po ciężkich walkach Maczkowi udało się wyzwolić Bredę bez strat wśród ludności cywilnej.

Wystawa prezentuje również pojazdy bojowe będące na uzbrojeniu jednostek pancernych dowodzonych przez gen. Maczka oraz daje dokładną charakterystykę znaków rozpoznawczych tych jednostek.

Do przygotowania wystawy wykorzystano około 200 zdjęć, pozyskanych z Narodowego Archiwum Cyfrowego, Centralnego Archiwum Wojskowego, Muzeum Wojska Polskiego w Warszawie, Muzeum Wojsk Lądowych 
w Bydgoszczy oraz zdjęcia i rysunki udostępnione przez Wydawnictwo Kageroo i Wydawnictwo Militaria.

W otwarciu wystawy uczestniczyli z ramienia UMK wicedyrektor Instytutu Historii i Archiwistyki prof. Jarosław Kłaczkow oraz Jacek Bilskiwiceprezes Stowarzyszenia Miłośników Artylerii i Militariów, Bogdan Wiśniewski - przedstawiciel Muzeum Wojsk Lądowych w Bydgoszczy oraz Andrzej Szukalski - członek naukowego Koła Historii UMK, który zaprezentował umundurowanie i wyposażenie osobiste żołnierzy 1. Dywizji Pancernej.

Wystawa była eksponowana w nowym gmachu Collegium Humanisticum na Bielanach.

Jacek Bilski 